UNIO - EU Law Journal. Vol. 5, No. 2, July 2019, pp 103-127.

®2019 Centre of Studies in European Union Law

School of Law - University of Minho

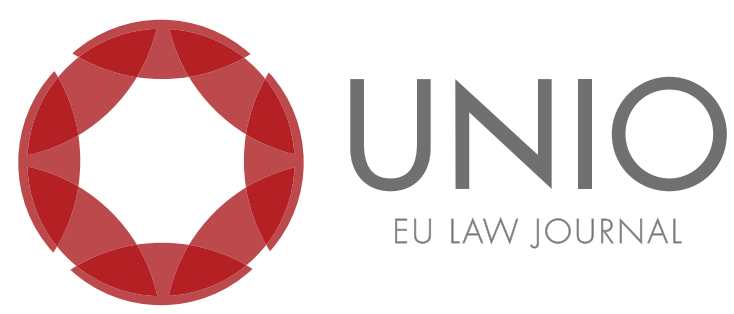

\title{
You can't have your cake and eat it too: Portugal and the self-determination of Western Sahara
}

\section{Francisco Pereira Coutinho*}

ABSTRACT: Western Sahara self-determination posits a conundrum to Portuguese foreign policy. Moral and legal imperatives which stem from the relentless efforts taken in the 80's and the 90's advocating in international fora the self-determination of East Timor impel the pursuit of an idealistic diplomacy of unconditional support for the akin self-determination of Western Sabara. Political, strategic, economic, historical and cultural ties dictate a realpolitik aimed at fostering diplomatic relations with Morocco without shunning Algeria, another key stakeholder in the Maghreb region. These constraints motivated the adoption of an impartial and equidistant position towards the Western Sahara conflict. This strategy was exposed after the Court of Justice ceased in Front Polisario, the de facto application of the EU/Morocco agreements in Western Sahara. Notwithstanding multiple pledges to the contrary, the Portuguese Government picked Morocco's side in the conflict by lodging written interventions aimed at neutralizing the Court of Justice of the EU, and by approving Council decisions that expressly extend EU/Morocco agreements to Western Sabara in breach of EU and international law.

KEYWORDS: access to documents - decolonization - international agreements - selfdetermination - Western Sahara.

\footnotetext{
* Professor at the Faculdade de Direito da Universidade Nova de Lisboa (Lisbon Nova Law School).
} Member of CEDIS - R \& D Research Center for Law and Society. 


\section{Introduction}

Self-determination has haunted Portuguese foreign policy ever since it was expressly recognized on the Declaration on the Granting of Independence to Colonial Countries and Peoples of 14 December 1960. ${ }^{1}$ The staunch refusal to decolonize became the Achilles heel of Portuguese diplomacy, ${ }^{2}$ which was unable to avoid the gradual transformation of the country into a pariah in the international society. ${ }^{3}$ The "carnation revolution" from 25 April 1974 brought democracy and the rule of law, but also a chaotic decolonization at the peak of the cold war, which left one colony (East Timor) occupied and annexed by a neighbouring State (Indonesia). Guilt complex turned the self-determination of the Timorese people into a national cause that crossed the political spectrum and a leitmotiv of foreign policy. The independence of East Timor (2002) was a moment of triumph (and joy) of Portuguese diplomacy (and people).

Dealing with Western Sahara's self-determination was always a conundrum. Portugal does not recognize the annexation of Western Sahara by Morocco and supports the UN efforts to secure a political solution for the conflict that would allow the Sahrawi people to exercise their right to self-determination, ${ }^{4}$ while simultaneously electing Morocco as a prime partner for economic diplomacy with whom it has strengthened political ties through the adoption of international agreements in multiple fields. ${ }^{5}$

\footnotetext{
1 "Immediate steps shall be taken, in Trust and Non-Self-Governing Territories or all other territories which have not yet attained independence, to transfer all powers to the peoples of those territories, without any conditions or reservations, in accordance with their freely expressed will and desire, without any distinction as to race, creed or colour, in order to enable them to enjoy complete independence and freedom". UN Assembly General Resolution 1514 (XV) on the Declaration on the Granting of Independence to Colonial Countries and Peoples (December 14, 1960), para.5.

${ }^{2}$ According to Salazar, the de facto leader of the "Estado Novo" regime, "( $\left.t\right)$ he fact of a territory proclaiming its independence is a natural phenomenon in human societies and, therefore, it is a bypothesis that is always admissible", "but indeed no one can or ought to set a time limit for it. What is being subjected to timetables is the inconceivable politics of our time, which claim that states should set a time limit to destroy their unity and break up" (Gene Farmer, "Dictator on the Defensive. An Exclusive Talk with Portugal's Enigmatic Salazar", Time Magazine, May 4, 1962, 99).

${ }^{3}$ See Bruno Cardoso Reis, "Portugal and the UN: A Rogue State Resisting the Norm of Decolonization (1956-1974)", Portuguese Studies 29, No. 2 (2013): 251-76.

4 "(Portugal) supports a just and lasting solution that would provide for self-determination of the people of Western Sahara" (Declaration of vote of the Representative of Portugal, UN General Assembly, Fourth Committee, $9^{\text {th }}$ Meeting, "Fourth Committee Approves Text on Western Sahara at Conclusion of Debate on Decolonization Issues", GA/SPD/348, October 13, 2006). See also: Ministério dos Negócios Estrangeiros, "Resposta à pergunta No. 494/XI/1. Ofício No. 57, de 7 de janeiro de 2010", Diário da Assembleia da República, Série B, No. 33/XI/1, January 8, 2010, 193; Ministério dos Negócios Estrangeiros, "Resposta à pergunta No. 1428/XX/2. Ofício No. 1659, de 4 de abril de 2013", Diário da Assembleia da República, Série B, No. 132/XII/2, April 8, 2013, 101; Ministério dos Negócios Estrangeiros, "Resposta à pergunta No. 1030/XII/2. Ofício No. 4010, de 19 de setembro de 2013", available at https:/ / www.parlamento.pt/ActividadeParlamentar/Paginas/DetalhePerguntaRequerimento.aspx?BID=74716 (accessed on June 25, 2019); Ministério dos Negócios Estrangeiros, "Resposta à pergunta No. 1176/XII/4. Ofício No. 3714, de 23 de junho de 2015”, available at https://www.parlamento.pt/ ActividadeParlamentar/Paginas/DetalhePerguntaRequerimento.aspx?BID=86443 (accessed on June, 25, 2019); or Ministério dos Negócios Estrangeiros, "Resposta à pergunta No. 3107/XIII/1. Ofício No. 5349, de 12 de outubro de 2016", available at https:/ /www.parlamento.pt/ActividadeParlamentar/ Paginas/DetalhePerguntaRequerimento.aspx?BID=96088 (accessed on June 25, 2019).

${ }^{5}$ Madalina Dobrescu, Tobias Schumacher and Stelios Stavridis, "Southern Europe: Portugal, Spain, Italy, Malta, Greece, Cyprus” in Foreign Policies of EU Member States: Continuity and Europeanisation, ed.
} 
However, there is no diplomatic magic that allows for one "having a cake and eating it too". Not even the Portuguese. On the one hand, on 11 May 2018, the Portuguese Parliament approved a vote of solidarity, proposed by the Communist Party and voted by the Socialist Party, which declares that a "fair and lasting solution for the Western Sahara conflict requires the end of Morocco's illegal occupation of Western Sahara and its policy of disrespect for the rights of the Sahrawi people", and calls on the government to deliver a foreign policy in international institutions which supports the right to self-determination of the Sahrawi people. ${ }^{6}$ On the other hand, on 28 January 2019 and 4 March 2019, respectively, the Portuguese Government also Socialist - voted the approval of European Union (EU) Council decisions which expressly extend to Western Sahara the application of EU/Morocco agreements. ${ }^{7}$ The Council decisions are a reaction to the Court of Justice's rulings in Front Polisario and Western Sahara Campaign, which declared that EU/Morocco agreements could not be applied in Western Sahara as that would be incompatible with the principles of selfdetermination and of the relative effect of Treaties. ${ }^{8}$

In this article, I argue that the territorial extension to Western Sahara of EU/ Morocco agreements is invalid under the Treaties because it breaches international law, namely the EU's obligation of non-recognition of an unlawful situation, which is the occupation and annexation of Western Sahara by Morocco (sections one to four). The Portuguese Government's endorsement of the EU/Morocco agreements is consistent with previous practice, ${ }^{9}$ which is reflected in the written interventions presented in Front Polisario and Western Sahara Campaign, but directly contradicts the Parliament's call (section five).

Amelia Hadfield, Ian Manners, Richard G. Whitman (Routledge, 2017), 90.

${ }^{6}$ Voto No. 537/XIII/3, "De solidariedade com o povo saraui pelo respeito e concretização do seu direito à autodeterminação, apresentado pelo PCP e subscrito por uma Deputada do PS, que foi aprovado", Diário da Assembleia da República, I Série, No. 84, May 12, 2018, 60-61.

${ }^{7}$ Council Decision (EU) 2019/217 of 28 January 2019 on the conclusion of the agreement in the form of an Exchange of Letters between the EU and the Kingdom of Morocco on the amendment of Protocols 1 and 4 to the Euro-Mediterranean Agreement establishing an association between the European Communities and their Member States, of the one part, and the Kingdom of Morocco, of the other part. Council Decision (EU) 2019/441 of 4 March 2019 on the conclusion of the Sustainable Fisheries Partnership Agreement between the EU and the Kingdom of Morocco, the Implementation Protocol thereto and the Exchange of Letters accompanying the Agreement. According to media reports, Sweden was the only Member State which abstained on the amendment to the Euro-Mediterranean Agreement (EuroMesco, "EU Council adopts decision amending its Association Agreement with Morocco and concludes negotiations on the fishery agreement with Morocco", July 24, 2018, available at https://www.euromesco.net/news/eu-council-adopts-decisionamending-its-association-agreement-with-morocco-and-concludes-negotiations-on-the-fisheryagreement-with-morocco/) (accessed on June 15, 2019) and voted against the fisheries agreement (Western Sahara Resource Watch, "European Council approves new fish deal, Sweden objects", December 6, 2018, available at https:/ / www.wsrw.org/a105x4346 (accessed on June 15, 2019).

${ }^{8}$ Judgment of December 21, 2016, Council v Front Polisario, C-104/16 P, EU:C:2016:973, para. 123, and Court of Justice, judgment of February 27, 2018, Western Sahara Campaign, C-266/16, ECLI:EU:C:2018:118, para. 63.

9 “ $(. .).(T) h e$ Fisheries Agreement between the (EU) and Morocco does not breach the international legislation applicable to Western Sahara" (Ministério dos Negócios Estrangeiros, "Pergunta No. 1917/ XI/1", March 16, 2010, Diário da Assembleia da República, Série B, No. 111/XI/1, de April 27, 2010, 149). See also Ministério dos Negócios Estrangeiros, "Resposta à pergunta No. 494/XI/1. Ofício No. 57, de 7 de janeiro", Diário da Assembleia da República, Série B, No. 33/XI/1, January 8, $2010,193$. 


\section{The endless tale of Africa's last colony}

After the Berlin Conference of 1884, Spain colonised the Western Sahara, a desertic territory bathed by the Atlantic Ocean located to the south of the Canary Islands which was then inhabited by nomad Berber tribes.

A few weeks before the adoption of the Declaration on the Granting of Independence to Colonial Countries and Peoples, Spain recognized Western Sahara as a non-autonomous territory and started to provide information about the territory to the Secretary-General of the UN pursuant to Chapter XI of the UN Charter. ${ }^{10}$ Notwithstanding multiple UN General Assembly resolutions affirming the right of the Sahrawi people to self-determination, ${ }^{11}$ only after Franco's withdrawal from the executive office did Spain inform the UN Secretary General United of its decision of calling a referendum on self-determination in Western Sahara in the first six months of 1975 under UN supervision. ${ }^{12}$

The organization of a referendum on self-determination ran against the interests of Morocco, which from the outset of its own independence in 1956 considered the Western Sahara to be a part of its territory. ${ }^{13}$ Moroccan sovereignty claims over Western Sahara were rebuffed in an Advisory Opinion of the International Court of Justice:

The materials and information presented to the Court show the existence, at the time of Spanish colonisation, of legal ties of allegiance between the Sultan of Morocco and some of the tribes living in the territory of Western Sahara. They equally show the existence of rights, including some rights relating to the land, which constituted legal ties between the Mauritanian entity, as understood by the Court, and the territory of Western Sahara. On the other hand, the Court's conclusion is that the materials and information presented to it do not establish any tie of territorial sovereignty between the territory of Western Sahara and the Kingdom of Morocco or the Mauritanian entity. Thus the Court has not found legal ties of such a nature as might affect the application of [Resolution of the UN General Assembly of 14 December 1960, 1514 (XV) on the granting of independence to colonial countries and peoples ('Resolution 1514 (XV)')] in the decolonization of Western Sahara and, in particular, of the principle of selfdetermination through the free and genuine expression of the will of the peoples of the Territory. ${ }^{14}$

Morocco was not convinced. Considering that "everyone" had recognized that Western Sahara belonged to Morocco and that "it only remained for the Moroccans to occupy (their) territory", King Hassan II of Morocco ordered a "peaceful march" towards Western Sahara which included 350000 persons. ${ }^{15}$ The "Green March" was deplored by the Security Council, which called upon Morocco to immediately withdraw

\footnotetext{
${ }^{10}$ United Nations (UN) General Assembly (Fourth Committee), 1047 ${ }^{\text {th }}$ Meeting of November 11, 1960, UN Doc. A/C.4/SR.1047.

11 UN General Assembly Resolution 2072 (XX) (December 16, 1965); UN General Assembly Resolution 2229 (XXI) (December 20, 1966); UN General Assembly Resolution 2354 (XXII) (December 19, 1967).

${ }^{12}$ Letter of August 20, 1974 of the Spanish Ambassador to the UN Secretary General José quoted by Ignacio Algueró Cuervo, El Sahara y España: claves de una descolonización pendiente (Santa Cruz de Tenerife: Idea, 2006), 407.

${ }^{13}$ Judgment of the General Court of December 10, 2015, Front Polisario v Council, T-512/12, ECLI:EU:T:2015:953, para. 1.

${ }^{14}$ Western Sahara, Advisory Opinion of October 16, 1975, ICJ Reports 1975, 12, para. 162.

15 Judgment of the General Court of December 10, 2015, Front Polisario v Council, T-512/12, ECLI:EU:T:2015:953, para. 9.
} 
from the territory of Western Sahara all the participants in the march. ${ }^{16}$ Morocco complied a few days later. ${ }^{17}$

Shortly afterwards, Spain, Morocco and Mauritania adopted the "Madrid Agreement", which established a temporary tripartite administration of Western Sahara with the collaboration of the Yema'a. ${ }^{18}$ The agreement foresaw the termination of the Spanish presence in Western Sahara to be completed by 28 February 1976 at the latest, and that "the views of the Saharan population, expressed through the Yema'a, [would] be respected". ${ }^{19}$ Two days before the deadline, Spain informed the UN Secretary General that of that date, it was definitely terminating its presence in Western Sahara and considered itself exempted from any international responsibility stemming from the administration of that territory. ${ }^{20}$

After the Spanish retreat, an armed conflict started in Western Sahara between Morocco and Mauritania, on one side, and the Frente Popular para la Liberación de Saguia el Hamra y Rio de Oro ("Front Polisario"), the Sahrawy national liberation movement created on 10 May 1973, ${ }^{21}$ on the other. The Western Sahara was effectively partitioned between Morocco (the northern two-thirds) and Mauritania (the remaining third in the south). ${ }^{22}$ In the interior regions bordered to Algeria which it was able to control, the Polisario Front proclaimed on 27 February 1976 the Saharan (Sahrawi) Arab Democratic Republic (SADR), ${ }^{23}$ which aspires to the administration over the whole Western Sahara. ${ }^{24}$

A peace agreement between Mauritania and Front Polisario was reached on 10 August 1979 under which Mauritania renounced to any territorial claim to Western

${ }^{16}$ Resolution 380 (1975) (November 6, 1975), para. 2

${ }_{17}$ Advocate General Wathelet, Opinion delivered on January 10, 2018, Western Sahara Campaign, C-266/16, ECLI:EU:C:2018:1, para. 155.

${ }^{18}$ The Yema'a was an advisory body established in 1967 by the Spanish administration composed of 103 members, including the mayors of large towns, tribal chiefs (sheiks), representatives of family groups and representatives of professional groups of Western Sahara. See Advocate General Wathelet, Western Sahara Campaign, C-266/16, ECLI:EU:C:2018:1, footnote 115.

19 "Declaration of Principles on Western Sahara by Spain, Morocco and Mauritania, of 14 November 1975”, UNTS, Vol. 988, 1975, 259.

20 "Letter Dated 26 February 1976 from the Permanent Representative of Spain to the UN Addressed to the Secretary-General (February 26, 1976)", UN Doc A/3156 S/11997, 2-3.

${ }^{21}$ According to Article 1 of its constituting document, the Front Polisario is "a national liberation movement, the fruit of the long resistance of the Sahrawi people against the various forms of foreign occupation" (Court of Justice, judgment of February 27, 2018, Council v Front Polisario, C-104/16 P, ECLI:EU:C:2016:973, para. 21).

${ }^{22}$ Article 1 of the Convention on the line of the State border established between the Islamic Republic of Mauritania and the Kingdom of Morocco, signed in Rabat on April 14, 1976, UNTS, Vol. 1035, I-15406, 1977, determined that the frontier was defined by a straight line running from the point at which the Atlantic coastline intersects the $24^{\text {th }}$ parallel North to the point of intersection of the $23^{\text {rd }}$ parallel North and the $13^{\text {th }}$ meridian West.

${ }^{23}$ In 2018, the SADR was recognized by forty-six States [Stephen Orvis, Carol Ann Drogus, Introducing Comparative Politics: Concepts and Cases in Context, $4^{\text {th }}$ Edition (Thousand Oaks, CA: Sage, 2018), 40]. The recognition of the SADR by the Organization of the African Union (now African Union) led Morocco to leave the organization in November 1984, only to return on January 2017 (Abdellah Saaf, "Morocco's great return to the African Union", Policy Brief, OCP Policy Center, February 2017, 1-2). Although it does not recognize the SADR, Portugal keeps informal contacts with representatives of the Polisario Front [Ministério dos Negócios Estrangeiros, "Resposta ao Requerimento No. 1246/ VII/1. a Ofício No. 2554, de 9 de setembro de 1996", Diário da Assembleia da República, Série B, No. 36/ VII/1 Supl., October, 10, 1996, 222 (19)].

${ }^{24}$ Clemens Feinäugle, "Western Sahara (Advisory Opinion)", in Max Planck Encyclopedia of Public International Law, cood. Rüdiger Wolfrum (Oxford: Oxford University Press, 2007), para. 18. 
Sahara. ${ }^{25}$ Morocco immediately stated that it would not agree to the creation of a "mini-State under the Front (Polisario) in Mauritania's sector of Western Sahara"26, and swiftly occupied and formally annexed the former Mauritanian territory in Western Sahara on 24 August 1979. ${ }^{27}$

On 21 November 1979, the UN General Assembly "reaffirm(ed) the inalienable right of the people of Western Sahara to self-determination and independence", "deeply deplore(d) the aggravation of the situation resulting from the continued occupation of Western Sabara by Morocco", "urge(d) Morocco to join in the peace process and to terminate the occupation of the Territory of Western Sahara" and "recommend(ed) to that end that the (Front Polisario), the representative of the people of Western Sahara, should participate fully in any search for a just, lasting and definitive political solution of the question of Western Sahara, in accordance with the resolutions and declarations of the (UN)." 28

The conflict between Morocco and the Front Polisario continued until a ceasefire, brokered by the UN Secretary-General Pérez de Cuellar, was agreed on 30 August 1988 and later implemented from 6 September $1991 .{ }^{29}$ Both parties accepted, in principle, to the organization of a referendum on self-determination under UN supervision. ${ }^{30}$

Since then, no significative progress towards allowing the people of Western Sahara to exercise its right to self-determination through a referendum has been achieved. ${ }^{31}$ The identification of the voters eligible to participate in a referendum was completed in May 2003 by an independent commission, but the parties continued to hold different views on the matter. ${ }^{32}$ The second version of the Baker plan which envisioned Sahrawi self-rule under a Western Sahara Authority for a period of four to five years, with a referendum on independence also opened to permanent residents in the Western Sahara to follow, ${ }^{33}$ was shortly afterwards endorsed by the UN Security Council, ${ }^{34}$ accepted by the Polisario Front, but formally rejected by Morocco, saying that it would no longer agree to any referendum which included independence as an

\footnotetext{
${ }^{25}$ Mauritano-Sabraoui Agreement, signed at Algiers (August 10, 1979). See annex to "Letter from the Permanent Representative of Mauritania to the UN addressed to the Secretary-General" (August 18, 1979), U.N. Doc. A/34/427 S/13503, August 20, 1979.

26 "Report of the Special Committee on the Situation with regard to the Implementation of the Declaration on the Granting of Independence to Colonial Countries and Peoples", (A/34/23/Rev.1), Official Documents of the General Assembly, Vol. II, 1977, 105-17, para. 32.

${ }^{27}$ According to Advocate General Wathelet, Opinion delivered on January 10, 2018, Western Sahara Campaign, C-266/16, ECLI:EU:C:2018:1, footnotes 44 and 45, the southern part of Western Sahara was incorporated into Morocco by Law (dahir) 2-79-430, August 14, 1979, Bulletin official du Royaume du Maroc, No. 3485, 489, and the northern part by Law 1-76-468 of August 6, 1976, Bulletin official du Royaume du Maroc, No. 3328, 914.

${ }^{28}$ U.N. Doc. A/RES/34/37 (November 21, 1979), paras. 1, 5 and 7.

29 "Letter Dated 8 July 1991 from the Secretary General Addressed to the Presidente of the Security Council”, U. N. Doc. S/22779, July 10, 1991.

${ }^{30}$ Report of the UN Secretary General, "The Situation Concerning the Western Sahara", U. N. Doc. S/21360, June 18, 1990, 4. The UN Security Council adopted Resolution 690 (1991) (April 29, 1991) creating the UN Mission for the Referendum in Western Sahara ('MINURSO') with the mandate to monitor the ceasefire and to organize and ensure a free and fair referendum. MINURSO's mandate was extended until 30 October 2019 by the Security Council Resolution 2468 (2019) (April 30, 2019).

31 Advocate General Wathelet, Opinion delivered on January 10, 2018, Western Sahara Campaign, C-266/16, ECLI:EU:C:2018:1, para. 181.

32 Thilo Marauhn, "Sahara", in Max Planck Encyclopedia of Public International Law, coord. Rüdiger Wolfrum (Oxford: Oxford University Press, 2010), paras. 33 and 34.

${ }^{33}$ UN Security Council, "Report of the Secretary-General on the situation concerning the Western Sahara", U. N. Doc. S/2003/565, May 23, 2003, Annex II.

${ }^{34}$ Resolution 1495 (2003) (July 31, 2003).
} 
option. ${ }^{35}$ This stand has frozen the political process because the Polisario Front (and Algeria) will not accept a solution of autonomy under Moroccan sovereignty that does not stem from a referendum. It is thus not foreseeable that the "new momentum", as the Security Council framed it in April 2019, ${ }^{36}$ created by round-table meetings between the parties and mutual commitments to engage in the UN political process, will lead to any substantial development on this thorny issue in the near future.

\section{Have the Sahrawi people exercised their right to self- determination?}

According to Principle VI of UN General Assembly Resolution 1541 (XV), the right to self-determination of a Non-Self-Governing territory such as the Western Sahara entails a choice between three options: i) independence; ii) association with another independent State; and iii) integration within an independent State. Such choice must reflect the "freely expressed will and desire" of the people concerned. ${ }^{37}$

Morocco argues that the Sahrawi people freely chose for Western Sahara to became an integrant part of its territory through an oath of allegiance to the King of Morocco pronounced on behalf of the Saharawi tribes by the President of the Yema'a (Khatri Ould Said a Ould El Jomaini) at a ceremony held on 4 November 1975 at the Palace of the Municipality of Agadir, ${ }^{38}$ and through a decision of the extraordinary meeting of the Yema'a held on 26 February 1976 which "expressed the unanimous opinion of the Saharawi populations and all the tribes of which it is the emanation and the authentic and legitimate representative". ${ }^{39}$ However, not only could the President of the Yema'a possibly claim to represent Sahrawi people, but also the meeting of 26 February 1976 was not attended by approximately two-thirds (67) of the members of the Yema'a. These members of the Yema'a unanimously had adopted, on 28 November 1975, the "Guelta Proclamation" which: i) declares that the Yema'a was not democratically elected by the people of Western Sahara and thus could not decide on its self-determination, ii) dissolves the Yema'a, and iii) considers the Polisario Front

\footnotetext{
35 "Reply of the Kingdom of Morocco to Mr. Baker's Proposal Entitled «Peace Plan for the SelfDetermination of Western Sahara»", in Security Council, "Report of the Secretary-General on the Situation Concerning Western Sahara", U. N. Doc. S/2004/325, April 23, 2004, 10-11. The first version of the Baker plan [Security Council, "Report of the Secretary-General on the situation concerning the Western Sahara”, S/2001/603, June 20, 2001, Annex I ("Framework agreement on the Status of Western Sahara")], which included a proposal for Western Saharan autonomy within the Moroccan State, was rejected by both the Polisario Front and Algeria (Thilo Marauhn, "Sahara", para. 34).

${ }^{36}$ Resolution 2468 (2019), April 30, 2019, recital 4.

${ }^{37}$ UN General Assembly Resolution 1514 (XV) (December 14, 1960), para. 5.

38 "I have come on behalf of all the inhabitants and tribes of the Sahara to render Your Majesty the allegiance of our ancestors. I have come out of patriotism because Sabara is an integral part of Morocco. We have never ceased to be Moroccans. When we saw that we had become a pawn, that our fate was literally put at risk by the appetites and ambitions of some, we decided to say what we think, loudly and clearly" ("Record of the $1954^{\text {th }}$ Meeting of the Security Council on 6 November 1975", S/PV.1854, February 29, 1984, para. 47). See also "Report of 8 November 1975 by the Secretary-General in application of Resolution 379 (1975) on the situation concerning Western Sahara", U. N. Doc. S/11874, November 8, 1975, para. 17.

${ }^{39}$ Annuaire de l'Afrique du Nord, Vol. 15, (1976), 847-48. In a message to the UN Secretary-General, the President of the Yema'a informed that "the Saharan Yema'a, meeting in special session today, Thursday February 26, 1976, in El Aaiun, has unanimously approved the reintegration of the Territory of the Sahara with Morocco and Mauritania, in conformity with the historical realities and with the links which have always united the Saharan population to these two countries" " Report of the Special Committee on the Situation with regard to the Implementation of the Declaration on the Granting of Independence to Colonial Countries and Peoples", U.N. Doc. A/31/23/Rev.1, Official Documents of the General Assembly, Vol. II, 1977, 203-25, para. 51).
} 
as the only legitime representative of the Sahrawi people. ${ }^{40}$ Not surprisingly, neither the UN nor Spain, as the administering Power of Western Sahara and member of the interim administration of Western Sahara established under the Madrid agreement, have recognized the oath or the Yema'a meeting of 26 February 1976 as reflecting the exercise of the right self-determination by the people of Western Sahara. ${ }^{41}$

Multiple Assembly General and Security Council Resolutions which have dealt with Western Sahara have stressed the need for the organization of a referendum on self-determination under UN supervision. ${ }^{42}$ Notwithstanding having agreed in principle to this methodology for the exercise of self-determination by the Sahrawi people, ${ }^{43}$ Morocco integrated Western Sahara in its territory by partition and annexation without consulting the people of Western Sahara and without UN supervision. ${ }^{44}$ It currently exercises a military occupation of roughly $80 \%$ of Western Sahara, ${ }^{45}$ including the coastline and the rich phosphate mining areas, and has built a 2,000 km wall of sand to separate and protect that territory from the area controlled by Front Polisario. ${ }^{46} \mathrm{~A}$ considerable number of refugees from Western Sahara live in camps administered by Front Polisario, situated in Algerian territory close to Western Sahara ${ }^{47}$ Being a clear breach of the right to self-determination, which is a legally enforceable right erga omnes and one of the essential principles of international law, ${ }^{48}$ Moroccan annexation of Western Sahara is not recognized by a single State. ${ }^{49}$

\section{The application of EU/Morocco agreements to the Western Sahara}

Morocco is a key element of the European Neighbourhood Policy, ranking first as a recipient of EU funding under the European Neighbourhood Instrument. ${ }^{50}$ Fighting

\footnotetext{
40 "Une date historique: la proclamation de Guelta", Sahara Info 60, 1982, VIII, paras. 1-3.

${ }^{41}$ Advocate General Wathelet, Opinion delivered on January 10, 2018, Western Sahara Campaign, C-266/16, ECLI:EU:C:2018:1, paras. 172-174 and 184.

${ }^{42}$ V.g. UN General Assembly Resolution 2229 (XXI) (December 20, 1966), paras. 4 and 5; UN Security Council Resolution 621 (1988) (September 20, 1988), para. 2; UN General Assembly Resolution 43/33 (November 22, 1988), para. 4; or UN Security Council Resolution 1084 (November 27, 1996), para. 1.

${ }^{43}$ Report of the UN Secretary General, "The Situation Concerning the Western Sahara”, U. N. Doc. S/21360, June 28, 1990, 4.

${ }^{44}$ Advocate General Wathelet, Opinion delivered on January 20, 2018, Western Sahara Campaign, C-266/16, ECLI:EU:C:2018:1, para. 183.

45 " (A) (t)erritory is considered occupied when it is actually placed under the authority of (an) hostile army" [Article 42 of Convention (IV) respecting the Laws and Customs of War and its annex: Regulations concerning the Laws and Customs of War (The Hague Convention), adopted on October 10, 1907 (entered into force January 26, 2010)].

${ }^{46}$ The wall, better known as "the Berm", is the longest defensive fortification in use today, and the second-longest ever, after China’s Great Wall (Nicolas Niarchos, "Is One of Africa's Oldests Conflicts Nearing its End?", The New Yorker, December 29, 2018, available at https://www.newyorker.com/ news/news-desk/is-one-of-africas-oldest-conflicts-finally-nearing-its-end, June 10, 2019).

${ }^{47}$ Judgment of the General Court of December 10, 2015, Front Polisario v Council, T-512/12, ECLI:EU:T:2015:953, para. 16.

${ }^{48}$ International Court of Justice, East Timor (Portugalv Australia), judgment, ICJ Reports 1995, 90, para. 29, and "Legal Consequences of the Construction of a Wall in the Occupied Palestinian Territory", Advisory Opinion, ICJ Reports 2004, 136, paras. 88 and 156.

${ }^{49}$ Sven Simon, "Western Sahara", in Self-determination and Secession in International Law, ed. Christian Walter, Antje von Ungern-Sternberg, Kavus Abushov (Oxford: Oxford University Press, 2014), 261.

${ }^{50}$ Members' Research Service, "How the EU Budget is Spent: European Neighbourhood Instrument", European Parliamentary Research Service Blog, November 22, 2016, available at https://epthinktank.
} 
terrorism and controlling illegal migration are major European political priorities which have to be dealt with with the collaboration of North African countries. ${ }^{51}$

EU/Morocco legal relations are structured by the Euro-Mediterranean Agreement, which is an Association Agreement signed in $1996 .{ }^{52}$ Under the scope of this agreement, the parties signed, inter alia, a Fisheries Partnership Agreement ${ }^{53}$ and a Fishing Protocol ${ }^{54}$, as well as an agreement liberalizing (processed) agricultural and fishery products ("Liberalisation Agreement") 55 and a aviation agreement. ${ }^{56}$ These agreements apply to "the territory of the Kingdom of Morocco" (Article 94 of the Association Agreement), to "the territory of Morocco and to the waters under Moroccan jurisdiction" (Article 11 of the Fisheries Partnership Agreement), to "Moroccan fishing zone(s)" (v. g. Article 2 of the Fishing Protocol), to Moroccan "land areas (mainland and islands), internal waters and territorial sea under its sovereignty or jurisdiction" [Article 1 (15) of the aviation agreement], and to products originating in Morocco [Article 17 (1) of the Association Agreement as amended by the Liberalisation Agreement].

Claiming that the Morocco/EU agreements were also being applied in Western Sahara, Front Polisario and a NGO (Western Sahara Campaign UK) brought several actions (before the General Court of the EU and an English court) where they argued for the invalidity of the EU law acts that had approved those agreements, namely on the ground that they are contrary to the general principles of EU law and to Article 3 (5) of the Treaty of the European Union (TEU), under which the Union is required to respect international law. ${ }^{57}$

eu/2016/11/22/how-the-eu-budget-is-spent-european-neighbourhood-instrument/ (June 11, 2019).

${ }^{51}$ Guillaume Van der Loo, "The Dilemma of the EU's Future Trade Relations with Western Sahara. Caught between strategic interests and international law?”, CEPS, April 20, 2018, 5.

52 The Euro-Mediterranean Agreement establishing an association between the European Communities and their Member States, of the one part, and the Kingdom of Morocco, of the other part, was signed in Brussels on 26 February 1996 (OJ 2000 L 70, 2) and approved on behalf of the Communities by Council and Commission Decision 2000/204/EC, ECSC of 24 January 2000 (OJ 2000 L 70, 1). Pursuant to Article 96 of the Agreement, it entered into force on 1 March 2000 (OJ 2000 L 70, 228).

${ }^{53}$ Fisheries Partnership Agreement between the European Community and the Kingdom of Morocco (OJ 2006 L 141, 4), as approved and implemented by Council Regulation (EC) 764/2006 of 22 May 2006. Pursuant to Article 17 of that regulation, it entered into force on 28 February 2007 (OJ 2007 L 78, 31).

${ }^{54}$ Protocol between the EU and the Kingdom of Morocco setting out the fishing opportunities and financial contribution provided for in the Fisheries Agreement (OJ 2013 L 328, 2). The conclusion of the protocol was approved by Council Decision 2013/785/EU of December 16, 2013. It entered into force on 15 July 2014 (OJ 2014 L 228, 1).

${ }^{55}$ Agreement in the form of an Exchange of Letters between the EU and the Kingdom of Morocco concerning reciprocal liberalisation measures on agricultural products, processed agricultural products, fish and fishery products, the replacement of Protocols 1,2 and 3 and their Annexes and amendments to the Euro-Mediterranean Agreement establishing an association between the European Communities and their Member States, of the one part, and the Kingdom of Morocco, of the other part, was signed in Brussels on December 13, 2010 (OJ 2012 L 241, 4), before being approved on behalf of the EU by the Council Decision 2012/497/EU, of March 8, 2012. It entered into force on October 1, 2012 (OJ 2012 L 255, 1).

${ }^{56}$ Euro-Mediterranean aviation agreement between the European Community and its Member States, of the one part and the Kingdom of Morocco, of the other part (OJ 2006 L 386, 57), as approved by Council Decision (EU) 2018/146 of 22 January 2018. It entered into force on 19 March 2018 (OJ 2019 L 6, 1).

57 General Court, judgment of December 10, 2015, Front Polisario v Council, T-512/12, ECLI:EU:T:2015:953, para. 159 and 200; Court of Justice, judgment of February 27, 2018, Western 
On a judgement from 10 December 2015, the General Court started by recalling that there is a divergence between the views of the EU and Morocco as to the international status of Western Sahara. While Morocco considers the Western Sahara to be an integral part of its territory, neither the Union nor its Member States recognizes that territorial claim. However, EU institutions were well aware that the Moroccan authorities were applying the provisions of the agreements to the part of Western Sahara it controlled and did not oppose that application. A subsequent practice had thus developed, which according to Article 31 (3) (b) of the Vienna Convention of the Law of the Treaties leads to an interpretation of the agreements as applying to Western Sahara. ${ }^{58}$

Front Polisario's argument that there is, under international law and EU law, an absolute prohibition against concluding an international agreement on behalf of the EU which may be applied to a territory in fact controlled by a non-member State, without the sovereignty of that State over that territory being recognized by the EU and its Member States or, more generally, by all other States, was rejected. ${ }^{59}$ The General Court considered that EU institutions enjoy a wide discretion as regards whether it is appropriate to conclude an agreement with a non-member State which will be applied on a disputed territory such as the Western Sahara ${ }^{60}$ However, the Council had an obligation - which it failed to fulfil - to examine in advance all the relevant facts of the individual case, and in particular to ensure that the application of the agreement was not carried out in a manner detrimental to the population of that territory and did not entail infringements of fundamental rights of the persons concerned. Accordingly, the Council decision that adopted the Liberalisation Agreement in so far as it approved its application to Western Sahara was annulled. ${ }^{61}$

Called on appeal by the Council, the Court of Justice overturned the judgment of the General Court and dismissed the action brought by Front Polisario by declaring that the EU/Morocco agreements are not applicable in Western Sahara.

The Court of Justice considered that the concept of "territory of the Kingdom of Morocco" included in the Association Agreement could only be construed as referring to the geographical area over which Morocco exercises the fullness of the powers granted to sovereign entities by international law, to the exclusion of any other territory, such as that of Western Sahara. ${ }^{62}$

If the territory of Western Sahara was to be included within the scope of the Association Agreement, that would be contrary to certain rules of general international law applicable in the relations between the EU and Morocco. First, it would breach the principle of self-determination, stated in Article 1 of the UN Charter, disregarding the "separate and distinct" status accorded by the international community to Western

Sahara Campaign, C-266/16, ECLI:EU:C:2018:118, para. 32; General Court, order of November 30, 2018, Front Polisario v Council, T-275/18, ECLI:EU:T:2018:869, para. 25.

${ }^{58}$ Judgment of 10 December 2015, Front Polisario v Council, T-512/12, ECLI:EU:T:2015:953, paras. 103. The rules laid down in the Vienna Convention of the Law of Treaties of May 23, 1969 (UNTS, Vol. 1155, 331) apply to an agreement concluded between a State and an international organisation in so far as the rules are an expression of general international customary law (Judgement of the Court of Justice of February 25, 2010, Brita, C-386/08, EU:C:2010:91, para. 41).

59 Judgment of the General Court of December 20, 2015, Front Polisario v Council, T-512/12, ECLI:EU:T:2015:953, para. 215.

${ }^{60}$ Id., para. 216-22.

${ }^{61} I d$., para. 223-47.

${ }^{62}$ Judgment of December 21, 2016, Council v Front Polisario, C-104/16 P, EU:C:2016:973, paras. 95 and 132. 
Sahara, which is listed since 1963 as a non-self-governing territory within the meaning of Article 73 of the UN Charter. Secondly, it would breach the principle of the relative effect of treaties under which a treaty must neither impose any obligations nor confer any rights on third States without their consent. ${ }^{63}$ According to the Court, the people of Western Sahara must be regarded as a "third party" within the meaning of the pacta tertiis principle. As such, the implementation of the EU/Morocco agreements in Western Sahara had to receive the consent of the representatives of the people of Western Sahara, and whether such implementation was likely to bring harm or benefit to that people was irrelevant. ${ }^{64}$

The same reasoning was adopted by the Court of Justice ${ }^{65}$ and by the General Court $^{66}$ to exclude the application to Western Sahara of the fisheries and the aviation agreements. ${ }^{67}$

${ }^{63}$ This general principle of international law, which is codified in Article 34 of the Vienna Convention of the Law of the Treaties, was applied by the Court of Justice in Brita, where it found that products originating in the occupied Palestinian territorial do not fall within the territorial scope of the EU/Israel Associated Agreement (judgement of February 25, 2010, C-386/08, EU:C:2010:91, paras. 52-53).

${ }^{64}$ Judgment of December 21, 2016, Council v Front Polisario, C-104/16, paras. 88-93, 100, 103-107 and 123-124.

${ }^{65}$ Court of Justice, judgment of February 27, 2018, Western Sahara Campaign UK, C-266/16, ECLI:EU:C:2018:118, para. 85. This ruling led the General Court to declared that Front Polisario had no standing to seek the annulment of the fisheries protocol (order of July 19, 2018, Front Polisario $v$ Council, T-180/14, ECLI:EU:T:2018:496, para. 70).

${ }^{66}$ General Court, order of November 30, 2018, Front Polisario v Council, T-275/18, ECLI:EU:T:2018:869, paras. 31-41.

${ }^{67}$ The application of international law in the Front Polisario rulings was both praised and criticized in the legal literature. See Álvaro De Elera, "The Frente Polisario Judgements: An Assessment in the Light of the Court of Justice's Case Law on Territorial Disputes", in The EU as a Global Actor: Bridging Theory and Practice, Liber Amicorum in hounour of Ricardo Gosalbo Bono, ed. Jeno Czuczai and Frederik Naert (Brill, 2017), 287 ("(t)he legal analysis by the Court may seem, under international law, immaculate and is certainly much closer to the orthodoxy of international and Union law"); Enrico Milano, "Front Polisario and the Exploitation of Natural Resources by the Administrative Power", European Papers 2, 3 (2017): 966 ("it is submitted that the judgment of the Court of Justice is an important milestone in the search for justice of the Sahrawi people and should be seen as ultimately Voelkerrechtsfreundlich"); Enzo Cannizzaro, "In defence of Front Polisario: The ECJ as a global jus cogens maker", Common Market Law Review 55, 2, (2018): 577, "(Front Polisario) could silently contribute to the development of one of the most controversial doctrines in international law, namely jus cogens"); Andrea Mensi, "The Case Western Sahara Campaign UK and the International and Institutional Coherence of European Union External Action. Opening Pandora's Box ?”, European Foreign Affairs Review 23, 4, (2018): 549 (“(t)he case represents a landmark decision on the relationship between the European Union and principles of customary international law"); Eva Kassoti, "The Council v. Fron Polisario", European Papers 23, 2 (2017): 41, and "The EU and Western Sahara: An Assessment of Recent Developments", European Law Review 43, 5 (2018): 759 ("the Court of Justice's reliance on international law was "selective and artificial"); Jed Odermatt, "Council of the European Union v. Front Populaire pour la liberation de la saguia-el-hamra et du rio de oro (Front Polisario) Case C-104/16", American Journal of International Law 111 (2017): 737-38 (“(Front Polisario) is an example of the Court «instrumentalizing» international law"); Peter Hilpold, "Self-Determination and the European Courts: The Front Polisario Case or the Unintended Awakening of a Giant", European Papers 2 (2017): 908 (“( $\mathrm{t}$ )hough purportedly relying on international law (the) findings by the EU courts are, however, not always really convincing from the viewpoint of the international legal order"); Javier Andrés González Vega, "La guerra de los mundos: realidad versus formalismo jurídico o el poder de la interpretación (a propósito de la sentencia TJUE de 27 de febrero de 2018, Western Sahara Campaign UK, C-266/16)", Revista de Derecho Comunitario Europeo 60 (2018): 515 ("the judgment of the Court (...) lies in a strictly formal appreciation of the case"); Rachel Frid de Vries, "EU Judicial Review of Trade Agreements involving Disputed Territories: Lessons from the Front Polisario Judgments”, 24, 2 (2018): 496 ("EU Courts' application of (public international law) principles left much to be desired"). 


\section{The invalidity of the new generation of EU/Morocco agreements applicable to Western Sahara}

Morocco retaliated to the General Court's Front Polisario ruling by suspending contacts with the EU in February 2016. A Cabinet statement declared that "Morocco cannot accept to be treated as a subject of a judicial process and to be buffeted between European institutions (...). Continuing in that position would deeply threaten the mutual trust and even the continuation of the partnership between the two sides." 68

A solution to the political turmoil quickly started to emerge. On the very day of the Court of Justice's decisions on the non-applicability to Western Sahara of EU/ Morocco agreements, the EU High Representative and the Moroccan Minister for Foreign Affairs issued joint statements where they took notice of the rulings and confirmed "their commitment to the strategic partnership between Morocco and the EU and their determination to preserve and reinforce it". ${ }^{69}$

Pressured by Spain and France, ${ }^{70}$ the Commission asked the Council for a mandate to negotiate with Morocco the inclusion of Western Sahara within the territorial scope of the EU/Morocco agreements affected by the rulings of the Court of Justice. ${ }^{71}$ Through agreements signed on 25 October $2018^{72}$ and 14 January $2019^{73}$, products originating in Western Sahara were given preferential treatment on

${ }^{68}$ Aziz El Yaakoubi, "Morocco suspends contacts with EU over court ruling on farm trade", Reuters, February 25, 2016, available at https://www.reuters.com/Article/us-eu-morocco-westernsaharaidUSKCNOVY26X (June 13, 2019).

${ }^{69}$ See "Déclaration conjointe par la Haute-Représentante de l’Union pour les affaires étrangères et la politique de sécurité et Vice-Présidente de la Commission européenne Federica Mogherini et le Ministre des Affaires étrangères et de la coopération du royaume du Maroc Salahddine Mezouar", December 21, 2016, available at http://eueuropaeeas.fpfis.slb.ec.europa.eu:8084/headquarters/ headquarters-homepage/18042/declaration-conjointe-par-federica-mogherini-et-le-ministre-desaffaires-etrangeres-et-de-la_en (accessed on June 13, 2019); "Joint statement by Federica Mogherini and the Minister for Foreign Affairs and Cooperation of the Kingdom of Morocco, Nasser Bourita", February 27, 2018, available at https:// eeas.europa.eu/delegations/morocco/40464/joint-statementfederica-mogherini-and-minister-foreign-affairs-and-cooperation-kingdom_en (accessed on June 13, 2019).

${ }^{70}$ Guillaume Van der Loo, "The Dilemma of the EU's Future Trade Relations with Western Sahara", 5.

${ }^{71}$ European Commission, "Recommendation for a Council Decision authorising the opening of negotiations on the adaptation of protocols to the Agreement between the EU and the Kingdom of Morocco", COM/2017/191 final, April 19, 2017; European Commission, "Recommendation for a Council Decision to authorise the Commission to open negotiations on behalf of the EU for the amendment of the Fisheries Partnership Agreement and conclusion of a Protocol with the Kingdom of Morocco", COM/2018/151 final, March 31, 2018. An action for annulment brought by Front Polisario against the Council decision that authorized the opening of negotiations of the fisheries agreement and protocol was dismissed by the General Court, which considered that the effects of such a decision are essentially political, and, therefore, cannot be considered as directly affecting the legal position of the applicant pursuant to Article 263 (4) TFEU (order of February 8, 2019, Front Polisario v Council, T-376/18, ECLI:EU:T:2019:77, para. 30).

${ }^{72}$ Agreement in the form of an Exchange of Letters between the EU and the Kingdom of Morocco on the amendment of Protocols 1 and 4 to the Euro-Mediterranean Agreement establishing an association between the European Communities and their Member States, of the one part, and the Kingdom of Morocco, of the other part (OJ L 34, February 6, 2019, 4-7). The conclusion of the agreement was approved by Council Decision (EU) 2019/217 of January 28, 2019.

${ }^{73}$ Sustainable Fisheries Partnership Agreement between the EU and the Kingdom of Morocco, the Implementation Protocol thereto and the Exchange of Letters accompanying the Agreement (OJ L 77, March 20, 2019, 8-55). The conclusion of the agreement was approved by Council Decision (EU) 2019/441 of March 4, 2019. 
the same terms of products covered by the Liberalisation Agreement, and Union fishing fleets were given access to the waters adjacent to the territory of Western Sahara.

These agreements will likely be short lived. Notwithstanding assurances of the EU institutions that the case law of the Court of Justice was taken into account, ${ }^{74}$ the new generation of EU/Morocco agreements applicable to Western Sahara are invalid under EU law because they are incompatible with Article 3(5) TEU, the first subparagraph of Article 21(1) TEU, Article 21(2)(b) and (c) TEU and Articles 23 TEU and 205 TFEU, which impose on the EU the obligation that its external action strictly observe international law.

Although the Court of Justice affirmed in Front Polisario "the separate and distinct status accorded to the territory of Western Sahara by virtue of the principle of selfdetermination, in relation to that of any Sate, including the Kingdom of Morocco", 75 the latter did not move an inch on its official position that "the Sahara region is an integral part of the national territory over which it exercises full sovereignty in the same manner as for the rest of the national territory", and "that any solution to this regional dispute should be based on its autonomy initiative". ${ }^{76}$

As declared by the UN General Assembly Resolution 34/37 of 21 November 1979, which is mentioned twice in the Front Polisario ruling of the Court of Justice, ${ }^{77}$ the Western Sahara is under "continued occupation" by Morocco. ${ }^{78}$ It goes without saying that, under international law, the occupation and annexation by Morocco of Western Sahara severely impedes the exercise of the right to self-determination of the Saharawi people, and is therefore, a breach of Morocco's obligation to respect that right. ${ }^{79}$

From the erga omnes character of the right of peoples to self-determination stem obligations which "are by their very nature the concern of all States" and, "in view of the importance of the rights involved, all States can be held to have a legal interest in their protection". ${ }^{80}$ States are thus "under an obligation not to recognise the illegal situation resulting from the (breach of an obligation erga omnes). They are also under an obligation not to render aid or assistance in maintaining the situation created by such (breach). It is also for all States, while respecting the UN Charter and international law, to see to it that any impediment, resulting from the (breach), to the exercise by the (...) people (...) of its right to self-determination is brought to an end'. ${ }^{81}$

\footnotetext{
${ }^{74} \mathrm{~V} . \mathrm{g}$. Press release of the Council, "EU - Morocco: Council adopts sustainable fisheries partnership agreement", March 4, 2019, available at https://www.consilium.europa.eu/en/press/pressreleases /2019/03/04/eu-morocco-council-adopts-sustainable-fisheries-partnership-agreement/ (June 16, 2019).

${ }^{75}$ Judgment of December 21, 2016, Council v Front Polisario, C-104/16 P, EU:C:2016:973, para. 92.

${ }^{76}$ See exchange of letters between the EU and the Kingdom of Morocco accompanying the Sustainable Fisheries Partnership Agreement between the EU and the Kingdom of Morocco, OJ L 77, March 20, 2019, 53-55.

${ }^{77}$ Judgment of December 21, 2016, Council v Front Polisario, C-104/16 P, EU:C:2016:973, para. 35 and 105.

${ }^{78}$ Para. 5. See also UN General Resolution 35/19 (November 11, 1980), para. 3. Portugal abstained in both resolutions.

${ }^{79}$ A similar conclusion regarding Israel and the breach of the right to self-determination of the Palestinian people was reached by the International Court of Justice in the advisory opinion on the Legal Consequences of the Construction of a Wall in the Occupied Palestinian Territory, advisory opinion of July 9, 2004, ICJ Reports 2004, 136, para. 122.

${ }^{80}$ Id., para. 155.

${ }^{81}$ Id., para. 159.
} 
The duty of non-recognition derives from the broadly recognized peremptory nature of the right to self-determination ${ }^{82}$, which not only proscribes third parties from recognizing as lawful a situation created by a serious breach of an ius cogens norm, ${ }^{83}$ but also renders void any international agreements that infringe upon it. ${ }^{84}$ The purpose of the duty of non-recognition is to prevent the validation of an unlawful situation by seeking to ensure that a fait accompli, such as an annexation in breach of the right to self-determination, does not consolidate and crystallize over time through the principle of effectivity into situations recognized by the international legal order. ${ }^{85}$

The EU agreed to the extension to Western Sahara agreements concluded with Morocco with the caveat that it stands by its position concerning the non-self-governing status of the territory and its right to self-determination. ${ }^{86}$ In other words, the adoption of agreement does not imply the recognition of Moroccan sovereignty over Western Sahara. ${ }^{87}$ The EU seems to be advocating that Morocco is the administering power of a non-self-governing territory, with whom it can enter into Treaties that benefit its people. ${ }^{88}$ This is, however, a legal non-starter as not only Spain is the still the sole de jure administrative power of Western Sahara, ${ }^{89}$ but Morocco has "categorically denied" having such status. ${ }^{90}$ By taking notice of Morocco's claim of Western Sahara as an

${ }^{82}$ See International Law Commission, "Draft articles on responsibility of States for internationally wrong acts with commentary", Yearbook of the International Law Commission, 2001, Vol. II, Part Two, 85; Federal Constitutional Court of Germany, order of October 26, 2004, 2 BvR 955/00, 1038/01, 97; Antonio Cassese, Self-Determination of Peoples: A Legal Reappraisal (Cambridge: Cambridge University Press, 2005), 133-36. According to Stefan Oeter, "Self-Determination", in The Charter of the United Nations: A Commentary, 3rd ed., ed. Bruno Simma, Daniel-Erasmus Khan, Georg Nolte, and Andreas Paulus (Oxford: Oxford University Press, 2012), Vol. I, 316, "it is beyond doubt that self-determination, as a purpose and principle of the UN Charter, constitutes a legally binding norm for all member States of the UN, as has been confirmed by a series of resolutions of the (General Assembly) and (Security Council), but also the jurisprudence of the (International Court of Justice), and State practice in the process of decolonization as well as in the cases of creation of new States in Europe after 1990".

${ }^{83}$ Article 41 (2) of Articles on Responsibility of States for Internationally Wrongful Acts, G.A. Res. 56/83, Annex, U.N. Doc. A/RES/56/83/Annex (December 12, 2001).

${ }^{84}$ Article 53 of the Vienna Convention on the Law of Treaties.

${ }^{85}$ Martin Dawidowicz, "The Obligation of Non-Recognition of an Unlawful Situation", in The Law of International Responsibility, ed. James Crawford, Alain Pellet, Simon Olleson, Kate Parlett (Oxford: Oxford University Press, 2010), 678.

${ }^{86}$ See exchange of letters between the EU and the Kingdom of Morocco accompanying the Sustainable Fisheries Partnership Agreement between the EU and the Kingdom of Morocco, OJ L 77, March 20, 2019, 53-55.

${ }^{87}$ Recital 10 of Council Decision (EU) 2019/217 of January 28, 2019 and recital 11 of Council Decision (EU) 2019/441 of March 4, 2019.

88 "(T)he Union does not prejudge the outcome of the UN political process on the final status of Western Sahara and has consistently reaffirmed its commitment to resolving the dispute in Western Sabara, presently listed by the UN as a non-self-governing territory, large parts of which are currently administered by the Kingdom of Morocco (...)" (emphasis added) (Point 3 of Council Decision (EU) 2019/217 of January 28, 2019 and point 4 of Council Decision (EU) 2019/441 of March 4, 2019).

${ }^{89}$ Eva Kassoti, "The Empire Strikes Back: The Council Decision Amending Protocols 1 and 4 to the EU-Morocco Association Agreement", European Papers 4, 1 (2019): 311-12, refers that the UN “still recognizes Spain as the de jure administering power of Western Sabara and Spain has relied on this status to extend its international jurisdiction in criminal matters to crimes committed in Western Sahara". See also Advocate General Wathelet, opinion of September 13, 2016, C-104/96, Council v Front Polisario, ECLI:EU:C:2016:677, paras. 188-191, and Advocate General Wathelet, opinion of January 10, 2018, Western Sahara Campaign, C-266/16, ECLI:EU:C:2018:1, paras. 225-232.

90 Court of Justice, judgment of February 27, 2018, Western Sahara Campaign, C-266/16, ECLI:EU:C:2018:118, para. 72. Morocco has also denied being an occupying power of the territory of Western Sahara, which means that this qualification cannot also be relied upon to grant Morocco 
integral part of its territory while accepting to enter into agreements applicable to an occupied territory, the EU breached its obligation not to recognise an illegal situation resulting from the breach of the right to self-determination. ${ }^{91}$

The new generation of EU/Morocco agreements also breaches the principle of the relative effects of Treaties. According to the Front Polisario ruling of the Court of Justice, the Western Sahara, as a non-self-governing territory, is a third party in relation to the EU and Morocco, which means that any agreement between them cannot be applicable to Western Sahara in the absence of express consent by its people. ${ }^{92}$

The Council considered that the Court's requirement of consent by the people of Sahara was met because in the "extensive" and "wide-ranging" consultations carried out in Western Sahara and in Morocco by the Commission and the European External Action Service, "the socioeconomic and political actors who participated in the consultations were clearly in favour of concluding the (agreements)" ${ }^{93}$ Front Polisario's rejection of the agreements was qualified as petty politics justified by the feeling that the agreements "would affirm the Kingdom of Morocco's position on the territory of Western Sahara."

The objection of the liberation movement, which is the official representative of the people of Western Sahara, ${ }^{95}$ is, by itself, an almost unsurmountable obstacle to the fulfilment of the criterion of express consent. ${ }^{96}$ Furthermore, serious doubts were cast about the integrity of the procedure of consultation of the Saharawi people, as $83 \%$ of the Western Sahara civil society actors that were allegedly contacted by the Commission and the European External Action Service claimed that they were never consulted and have rejected the agreements. ${ }^{97}$ These doubts were shared by Sweden:

"In view of the rejections to the consultation process and/ or the draft agreement, and particularly the objections of Polisario, the official representative of the people of Western Sahara in the UN process, Sweden is not satisfied that the outcome of the consultation process can be said

treaty-making capacity over the Western Sahara. See Advocate General Wathelet, Opinion delivered on January 10, 2018, Western Sahara Campaign, C-266/16, ECLI:EU:C:2018:1, para. 252-255.

${ }^{91}$ Advocate General Wathelet also considered that, by exploring Western Sahara resources under the agreements, the EU has directly breached the principle of self-determination, and arguably the principle of permanent sovereignty over natural resources as well as the rules of international humanitarian law applicable to the exploitation of natural resources on an occupied territory (opinion of January 10, 2018, Western Sahara Campaign, C-266/16, ECLI:EU:C:2018:1, paras. 143-186, 256-287). On the question of the exploitation of natural resources on Western Sahara, see Juan Soroeta Liceras, "La posición de la Unión Europea en el conflicto del Sahara Ocidental, una muestra palpable (más) de la primacía de sus intereses económicos y políticos sobre la promoción de la democracia y de los derecho humanos", Revista de Derecho Comunitario Europeo 34 (2009): 829-42; Sandra Hummelbrunner and Anne-Carlijn Prickartz, "It's not the Fish that Stinks! EU Trade Relations with Morocco under the Scrutiny of the General Court of the European Union", Utrecht Journal of International and European Law 32, 83 (2016): 28-29; Ben Saul, "The Status of Western Sahara as Occupied Territory under International Humanitarian Law and the Exploitation of Natural Resources", Sydney Law School, Legal Studies Research Paper No. 15/81, 2015, and Enrico Milano, "Front Polisario and the Exploitation", 953-66.

${ }^{92}$ Judgment of December 21, 2016, Council v Front Polisario, C-104/16 P, EU:C:2016:973, paras. 106107.

${ }^{93}$ Recital 11 of Council Decision (EU) 2019/441 of March 4, 2019, and Recital 10 of Council Decision (EU) 2019/217 of January 28, 2019. (emphasis added)

${ }^{94}$ Ibid.

${ }^{95}$ UN General Assembly Resolution 34/37 (November 21, 1979), para. 7.

${ }^{96}$ Eva Kassoti, "The Empire Strikes Back", 312 ("Front Polisario's objections cast considerable doubts on whether the criterion of consent of the peoples of the territory was fulfilled in casu').

${ }^{97}$ Western Sahara Resource Watch, "Here, the EU Commission is lying about WSRW - and 93 other groups", June 14, 2018, available at https://wsrw.org/a105x4180 (accessed on June 15, 2019). 
to constitute the free and informed consent of the people of Western Sahara". ${ }^{98}$

\section{The Portuguese interventions in Front Polisario and Western Sabara Campaign}

6.1. Member States can participate and influence judicial proceedings before the Court Justice of the EU by lodging written observations in preliminary references and by submitting statements supporting one of the parties. ${ }^{99}$

Only three Member States - France, Portugal and Spain - have intervened in both Front Polisario and Western Sahara Campaign, and all of them aligned with the Council and the Commission's positions.

Spain and France's interventions were very much expected. The fall out of the General Court's decision - the suspension of relations with the EU by Morocco was particularly detrimental to the economic and political interests of Spain $(90 \%$ of EU fishing vessels in Western Sahara have Spanish nationality) ${ }^{100}$ and France (an unconditional ally of Morocco on Western Sahara). ${ }^{101}$

Portugal's intervention was more surprising given its residual economic interests in the waters of Western Sahara ${ }^{102}$ and, particularly, the fact that it has always aspired to avoid damage caused by the Western Sahara conflict to its diplomatic relations with both Algeria and Morocco. ${ }^{103}$ Lisbon's recent emphasis on fostering an "economic

${ }^{98}$ Council of the EU, "Statement by Sweden", 10891/18 ADD2, July 13, 2018.

${ }^{99}$ See Article 23 and Article 40 of the Statute of Court of Justice of the EU (Protocol No. 3).

${ }^{100}$ Juan Soroeta Liceras, "La posición de la Unión Europea en el conflicto del Sahara Ocidental", 836. Spain was given 92 of the 110 fishing licenses to fish demersal species in the Western Sahara waters by Article 1 of Council Regulation (EU) 2019/440 of 29 November 2018 on the allocation of fishing opportunities under the Sustainable Fisheries Partnership Agreement between the EU and the Kingdom of Morocco and the Implementation Protocol thereto.

${ }^{101}$ Philip C. Naylor, "Spain, France and the Western Sahara: A Historical and Narrative Study of National Transformations", in International Dimension of the Western Sahara Conflict, ed. Yahia H. Zoubir and Daniel Volman (Santa Barbara, CA: Praeger, 1993), 32, and Yahia H. Zoubir, "Geopolitic and Realpolitik as Impediments to the Resolution of Conflict and Violations of International Law: the case of Western Sahara", in International Law and the Question of Western Sabara, ed. Karin Arts and Pedro Pinto Leite (The Netherlands: International Platform of Jurists for East Timor, 2007), 288-90.

102 Article 1 of Council Regulation (EU) 2019/440 of November 29, 2018 granted Portugal 14 (of 110) fishing vessel licenses for demersal species and a quota of $2 \%$ of the tonnage for large-scale small pelagic fishing in Western Sahara waters. In 2008, 15 Portuguese vessels captured 3.051 tonns of fish under the previous EU/Morocco fishing agreement (Ministério dos Negócios Estrangeiros, “Resposta à pergunta No. 201/XI/1. a. Ofício No. 6976, de 16 de dezembro”, Diário da Assembleia da República, Série B, No. 27/XI/1, December 23, 2009, 151).

103 "Taking in consideration the involvement of two strategic neighbouring countries, Algeria and Morocco, and with the objective of safeguarding the excellent bilateral relations which maintains with both countries, Portugal follows a position of strict impartiality (on the question of Western Sahara)" (Ministério dos Negócios Estrangeiros, "Resposta ao requerimento No. 284/X/2. . Ofício No. 8917, de 22 de dezembro", Diário da Assembleia da República, Série B, No. 16/X/2, 2. ${ }^{\circ}$ Supl., de December 28, 2006, 72; Ministério dos Negócios Estrangeiros, "Resposta ao requerimento No. 1290/X/2. . Ofício No. 6827, de 30 de abril”, Diário da Assembleia da República, Série B, No. 51/X/2, Supl., de July 31, 2007, 45; Ministério dos Negócios Estrangeiros, "Resposta ao requerimento No. 1325/X/2. a. Ofício No. 5417, de 2 de agosto", Diário da Assembleia da República, Série B, No. 51/X/2, Supl., de August 6, 2007, 38; Ministério dos Negócios Estrangeiros, "Resposta ao requerimento No. 1799/X/2. . Ofício No. 6448, de 14 de setembro de 2007”, Diário da Assembleia da República, Série B, No. 5/X/3, Supl. September 9, 2007, 144). On 9 November 2018, the Portuguese Government formally supported the proposal of the King of Morocco on the establishment of a political mechanism of dialogue between Morocco and Algeria, "two countries with whom Portugal maintains dense and privileged relations" [Communication of the Portuguese Government on the proposal of the Kingdom of Morocco of establishing a joint political mechanism of dialogue and 
diplomacy", ${ }^{104}$ as well as the election of the Maghreb region as a foreign policy priority, ${ }^{105}$ had moved it closer to Morocco's position for resolving the conflict by offering political autonomy to Western Sahara. ${ }^{106}$ However, an intervention in support of the Council in Front Polisario would be hardly reconcilable with Article 7(3) of the Portuguese Constitution that states that "Portugal recognises peoples' rights to self-determination and independence and to development, as well as the right of insurrection against all forms of oppression". It would also be at odds with the passionate support in the 90's for the self-determination of East-Timor, a non-self-governing territory which also was occupied and annexed by a neighbouring State (Indonesia). ${ }^{107}$

6.2. Accessing the Portuguese interventions lodged in the Front Polisario and Western Sahara Campaign cases revealed itself to be a herculean task.

My first step was to request from the Court of Justice access to those documents invoking the first subparagraph of Article 15 (3) TFEU, which gives "any citizen of the Union (...) a right of access to documents of the Union's institutions". The problem is that in accordance with the fourth subparagraph of Article 15(3) TFEU, the Court is subject to the system of access to documents of the institutions only when exercising its administrative tasks. ${ }^{108}$ Furthermore, Article 42 of the Charter of Fundamental Rights of the EU and EU secondary law only recognizes public access to European Parliament, Council and Commission documents. ${ }^{109}$ In light of the above, the Court refuses by default access to written statements and observations submitted by Member States in judicial proceedings. ${ }^{110}$

concertation with Algeria, 9 November 2018, available at https://www.portaldiplomatico.mne.gov.pt/ (accessed on June 24, 2019)].

${ }^{104}$ Ana Catarina Pereira Mendes Leal, “A Diplomacia Económica em Portugal no Século XXI - que Papel no Investimento Directo Português no Exterior?", Negócios Estrangeiros 11.1, (2007): 245-49.

${ }^{105}$ Diogo Noivo, "Portugal and the Maghreb: Time to renew the vows", IPRIS Lusophone Countries Bulletin 16 (2011): 4-6.

106 "(Portugal) noticed with interest the [Moroccan Initiative for the Negotiation of a Statute of Autonomy (for Western Sahara)] and considered that it is part of the efforts developed to break the impasse and achieve a fair, durable and acceptable political solution to all parties involved within the UN framework." (Final Declaration of the IX Portuguese/ Moroccan Summit of 26 March 2007, para. 20, quoted in Ministério dos Negócios Estrangeiros, "Resposta ao requerimento No. 1799/X/2. . Ofício No. 6448, de 14 de setembro de 2007", Diário da Assembleia da República, Série B, No. 5/X/3, September 9, 2007 145). This stands in sharp contrast with the position taken in 1996, when the Portuguese Government declared that a political solution to Western Sahara could not be delivered by Morocco and appealed to a swift organization of a referendum on self-determination (Ministério dos Negócios Estrangeiros, "Resposta ao Requerimento No. 1246/ VII/1. a Ofício No. 2554, de 9 de setembro de 1996”, Diário da Assembleia da República, Série B, No. 36/ VII/1 Supl. October 10, 1996, 222 (19).

${ }^{107}$ Francisco Pereira Coutinho e Francisco Briosa e Gala, "David and Goliath Revisited: A Tale About the Timor Leste/Australia Timor Sea Agreements", Texas Journal of Oil, Gas and Energy Law 10 no. 2 (2015): 434-36.

${ }^{108}$ Access to these documents is governed by Decision of the Court of Justice of the EU of October 11, 2016 concerning public access to documents held by the Court of Justice of the EU in the exercise of its administrative functions, OJ 2016 C 445, 3.

${ }^{109}$ Regulation (EC) No. 1049/2001 of the European Parliament and of the Council of May 30, 2001 regarding public access to European Parliament, Council and Commission documents.

${ }^{110}$ Information on Member States' positions and arguments before the Court could be obtained through the Reports for the Hearing made by the Judge-Rapporteur, but the Court limited access to these reports in 1994 and stopped producing them in 2012 (Per Cramér, Olof Larsson, Andreas Moberg and Daniel Naurin, "See You in Luxembourg? EU Governments' Observations Under the Preliminary Reference Procedure”, SIEPS 5 (2016): 17). 
After heading nowhere in the Court of Justice, I reached for the author of the documents. The representation of the Portuguese State before the Court of Justice of the EU is a competence of the European Affairs Department of the Portuguese Ministry for Foreign Affairs. ${ }^{111}$ My informal request for access was promptly refused based on the confidential nature of the documents, which allegedly dealt with institutional matters that have implications on Portuguese foreign policy, and on the fact that related judicial proceedings were pending in the Court of Justice of the EU.

Weeks later, I attended a conference on Western Sahara held in the Portuguese Parliament where I mentioned the content of the Foreign Office's reply to my request to a Member of Parliament, Jose Manuel Pureza, who is also a renowned public international law scholar. Shortly afterwards, the parliamentary group of the Bloco de Esquerda party, to which Pureza belongs, requested the Portuguese Government access to the statement for intervention of the Portuguese Republic in Front Polisario. The request voices the concern on whether Portugal adopted a different, or even contrary, understanding concerning the application to non-self-governing territories of the principles of self-determination and relative effect of Treaties compared to the one it had supported in the East Timor case before the International Court of Justice. ${ }^{112}$

The Ministry for Foreign Affairs' reply referred the parliamentary group to the Court of Justice, where the statement for intervention was sent to, and further states that the document does not interfere with the international legal statute of Western Sahara, as it merely questions the competence of the Court of Justice to control the external relations of the EU and to review acts of a third State vis-à-vis the Charter of Fundamental Rights of the EU. ${ }^{113}$ This is a quite cynic answer given that the Portuguese Government is well aware that the Luxembourg Court would never give the Parliament access to that document. It is thus a breach of Article 156 (e) of the Constitution which grants the Members of Parliament (the Assembly of the Republic) the power "(t)o request and obtain the elements, information and official publications they deem useful to the exercise of their mandate from the Government or the organs of any public entity" (emphasis added). ${ }^{114}$

My quest at this point seemed to have reached a dead-end, but the Court of Justice's Breyer decision delivered a couple of weeks earlier improved my chances. The Court ruled that written submissions linked to judicial proceedings drawn up by Member States and held by the Commission did come within the scope of Regulation 1049/2001, as "documents held by an institution" within the meaning of Article 2(3) of the Regulation. ${ }^{115}$ Legitimate interests of the Member States regarding such

\footnotetext{
111 Article 11 (2) (b) of the Decree-Law 121/2011, of December 29 (Organic Law of the Ministry for Foreign Affairs).

112 Grupo Parlamentar do Bloco de Esquerda, "Requerimento No. 180/XIII/2, de 10 de junho de 2017”, available at https://www.parlamento.pt/ActividadeParlamentar/Paginas/ DetalhePerguntaRequerimento.aspx?BID=102435 (acessed on June 25, 2019).

${ }^{113}$ Ministério dos Negócios Estrangeiros, "Resposta ao Requerimento No. 180/XIII/2 Ofício No. 4494, de 28 de julho de 2017”, paras. 1-2, available at https://www.parlamento.pt/ActividadeParlamentar/ Paginas/DetalhePerguntaRequerimento.aspx?BID=102435 (acessed on 25/06/2019).

${ }^{114}$ This right solely does not include access to documents classified as "State secrets" J.J. Gomes

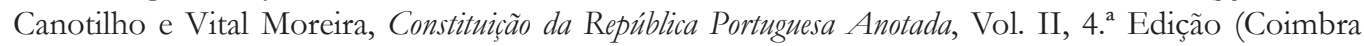
Editora, 2014), 270], which was not the case of the interventions lodged in the Court of Justice.

${ }^{115}$ Judgment of the Court of Justice of July 17, 2017, European Commission v Patrick Breyer, C-213/15 P, ECLI:EU:C:2017:563, para. 46. In para. 38, the Court declared that "the fact that Regulation No. $1049 / 2001$ does not apply to applications for access to documents in the possession of the Court of Justice of the EU does not mean that documents linked to that institution's judicial activity are, as a
} 
documents can be protected on the basis of the exceptions laid down in Regulation No. 1049/2001 to the principle of the right of access to documents, ${ }^{116}$ which allow the institutions to refuse access to a document, inter alia, where disclosure would undermine the protection of international relations (third indent of Article 4(1) (a) of the Regulation) or the protection of court proceedings if there is not an overriding public interest in disclosure (second indent of Article 4(2) of the Regulation).

Invoking Breyer, I asked the Commission for access to the statement for intervention submitted by Portugal in Front Polisario. My request was again denied. I was told that the Portuguese authorities, which were consulted in accordance with Article 4(4) of Regulation 1049/2001, had opposed the disclosure of the document based on the exceptions protecting international relations and court proceedings. ${ }^{117}$

Firstly, the Portuguese government contended that, although the official position on the question of Western Sahara was respected by the statement, the disclosure of the document "outside the context of the proceedings could be used to question the Portuguese position in the international legal order". ${ }^{118}$ The Commission apparently took this argument at face value and merely informed me that the protection of international relations is an absolute exception to the principle of access to documents.

Secondly, the Portuguese authorities considered that the disclosure of the statement could undermine the proceedings of a similar case (Western Sahara Campaign) which was at the time pending in the Court of Justice. The Commission did not contest this argument and referred to case law of the Court of Justice admitting the possibility that disclosure of pleadings relating to court proceedings, which are closed but connected to other proceedings that remain pending, may create a risk that the latter proceedings might be undermined. ${ }^{119}$ It further declared that it saw no elements capable of showing the existence of an overriding public interest in the disclosure of the document that would outweigh the public interest in the protection of the ongoing proceedings. ${ }^{120}$

I then asked the European Commission Secretary General to reconsider the position of the Commission. I argued that the Advocate General's opinion in Western Sabara Campaign was scheduled to be delivered in a month's time and that meant there was no possible risk for the integrity of court proceedings. Furthermore, I contended that the protection of the international relations of the State exception should not be applied to documents submitted in judicial proceedings which are no longer pending. In light of the principle of openness and transparency [Article 11(1) TEU], there is simply no good justification for the Court of Justice of the EU not to publish these documents in e-Curia as a rule. Even the International Court of Justice solely has discretion on whether the State's written submissions are accessible to the public on or after the opening of the oral proceedings. ${ }^{121}$ The case at hand, in which the Portuguese

matter of principle, outside the scope of the regulation where they are in the possession of the EU institutions listed in the regulation, such as the Commission."

${ }^{116} I d$., para. 39.

${ }^{117}$ European Commission, Ref.Ares(2017)5265127, October 27, 2017, 1.

${ }^{118} I d$., p. 2.

${ }^{119}$ Judgment of September 21, 2010, Sweden and Others v API and Commission, C-514/07 P, C-528/07 P and C-532/07 P, EU:C:2010:541, para. 132.

${ }^{120}$ European Commission, "Your request of 4 September 2017 registered under reference GestDem 2017/5020”, Ref.Ares(2017)5265127, October 27, 2017, 2-3.

${ }^{121}$ Articles 53 and 106 of the Rules of the International Court of Justice, adopted on April 14, 1978 (entered into force on July 1, 1978). All of the State's written submissions are available on the website 
Government somewhat contradictorily declared that its pleadings respected the official position on Western Sahara but at the same time could be used to question that same position, shows that documents, which should be in the public domain, cannot be enclosed by an arbitrary qualification by a State of what it considers to affect its international relations.

In response, the Commission's Secretary General informed me that the Portuguese authorities, which were again consulted, had a change of heart and agreed to partial disclosure of the statement for intervention submitted in Front Polisario. The limited undisclosed parts of the document were redacted on the basis of the exceptions relating to the protection of international relations and court proceedings. The Portuguese Government considered that full disclosure of the document would undermine the position of the country; "in the ongoing discussions under the auspices of the UN concerning the issue of Western Sahara" and the proceedings in the pending Western Sahara Campaign case in the Court of Justice. The Commission again agreed with the arguments of the Portuguese authorities stating that the undisclosed parts of the document risked "disturbing the negotiating equilibrium" of the ongoing discussions within the UN. Full disclosure would also breach the principles of equality of arms and fair trial because "the premature disclosure of the redacted parts of the document concerned could provoke a public debate on the position of the Portuguese authorities in (the discussions in the UN) and the criticism deriving therefrom could influence the position defended in the courts of the Union calling into question the equality of the parties and undermining the principle (of) the proper administration of justice". ${ }^{122}$

The arguments against full disclosure are ludicrous. The Portuguese statement for intervention submitted in Front Polisario has 1937 words. I was sent a document in which 39 words out of two paragraphs are omitted. These paragraphs simply mention that the Council did not adopt a manifestly inadequate measure in view of the objective it aimed to achieve and had only the obligation to ensure that the agreement with Morocco was not detrimental to the population of Western Sahara. ${ }^{123}$ It goes without saying that there was not even a remote possibility that these paragraphs could disturb the "negotiating equilibrium" of the UN negotiations over Western Sahara, in which Portugal is not even a party at the table, or of breaching the principle of equality of parties or of undermining the proper administration of justice in the Western Sahara Campaign case, which was concluded only a couple of weeks after the Commission's refusal to grant me full access to the statement.

My following request for access to the written observation submitted by the Portuguese State in Western Sabara Campaign met a similar response. The Commission deferred again to the Portuguese authorities' argument that full disclosure, not only; "would be negatively affecting the international relations by compromising the Portuguese position on the question of the Westerns Sahara as well as misinterpreting it at international level", but also would risk undermining proceedings to yet another case (T-376/18) concerning the question of Western Sahara pending in the General Court. ${ }^{124}$ In the omitted fragments of the observations, the Portuguese Government

of the International Court of Justice (https://www.icj-cij.org/).

${ }^{122}$ European Commission, "Your confirmatory application for access to documents under Regulation (EC) No. 1049/2001 - GestDem 2017/5020”, C(2018) 772 Final, February 5, 2018, 1-6.

${ }^{123}$ Ministério dos Negócios Estrangeiros, "Articulado de Intervenção da República Portuguesa no Processo No. C-104/16 P Conselho/Frente Polisário”, May 23, 2016, paras. 10 and 21.

${ }^{124}$ European Commission, "Your requests of 9 December 2018 registered under referenced GestDem 2018/6573 and GestDem 2018/6574”, February 7, 2019, 1-3. 
argued that the applicable customary international law principles lacked direct effect and could not be invoked by the applicant to question the validity of a Council decision that approved an international agreement. ${ }^{125}$

Meanwhile, I had formally requested from the Portuguese Ministry for Foreign affairs full access to the documents under Article 5(1) of Law 26/2016, of 22 of August, which recognizes to "everyone, without the need to invoke any interest, right of access to administrative documents". The Ministry for Foreign Affairs considered that the written statement and observations were not administrative documents and refused my request stating that I should contact the Court of Justice in order to obtain the documents.

I then presented a complaint against the refusal of access to the documents in the Commission for Access to Administrative Documents (CADA). This is an independent administrative entity established in the Portuguese Parliament (Article 28(1) of Law 26/2016). On 19 February 2019, in a landmark opinion for transparency and governmental accountability, CADA declared that copies of interventions of the Portuguese State in closed legal proceedings before the Court of Justice held by the Administration are accessible under the Law 26/2016, of 22 of August. ${ }^{126}$ In a nutshell, CADA considered that documents issued by an administrative entity do not change their administrative nature just because they were produced in the context of judicial proceedings. ${ }^{127}$ Quoting Breyer at length, CADA also declared that it made no sense for someone to obtain a document from the Commission but not directly from a Member State. ${ }^{128}$ The arguments against disclosure brought by the Ministry for Foreign Affairs related to the protection of the international relations of the Portuguese State and the integrity of judicial proceedings in the Court of Justice were declared hypothetical and not substantiated. ${ }^{129}$

The Portuguese Ministry for Foreign Affairs accepted CADA's opinion and approximately two years after my initial request - sent me a non-erased version of the documents on 6 March 2019.

6.3. The statement and the written observations submitted by Portugal in Front Polisario and Western Sahara Campaign seem, at first sight, to have been drafted in order to avoid taking a position on the legal and political controversies that surround the Western Sahara conflict.

The Portuguese government starts by claiming that its intervention does not; "impair or interfere with the situation and the international status of the Western Sahara territory" and is limited to an analysis of questions related to the scope of the ius tractandi of the Union ${ }^{130}$. No position is in fact taken regarding the validity vis-à-vis international law of the EU law acts that approved the EU/Morocco agreements. Portugal claims in Front Polisario the General Court's lack of jurisdiction to review the Council's discretion in the field of the EU's external economic relations, and rejects the application of the

\footnotetext{
${ }^{125}$ Ministério dos Negócios Estrangeiros, “Observações da República Portuguesa no Processo No. C-266/17 Western Sahara Campaign”, July 27, 2016, paras. 16-18 and 22-24.

126 Opinion 59/2019, of 19 February, case 829/2018, available at http://www.cada.pt/uploads/ Pareceres/2019/059.pdf (June 23, 2019)

${ }^{127} I d$., paras. $11-13$.

${ }^{128} I$ Id. paras. $16-19$.

${ }^{129} I$ d., paras. 24 and 28.

${ }^{130}$ Ministério dos Negócios Estrangeiros, "Intervenção da República Portuguesa no Processo No. C-104/16 P Conselho/Frente Polisário”, May 23, 2016, para. 5.
} 
Charter of Fundamental Rights of the EU in Western Sahara. ${ }^{131}$ Furthermore, Portugal argues in Western Sabara Campaign that the validity of the EU law acts which approved the EU/Morocco agreements could not be determined by reference to Article 3(5) TEU, and that the plaintiff had no standing to invoke rules of international law. ${ }^{132}$

A careful reading of the written statement and observations reveal, however, an intervention of the Portuguese State which, paying lip service to Moroccan interests in the conflict, disregards the "international status" of Western Sahara and the right to self-determination of the Sahrawi people, particularly when it qualifies Western Sahara as a "disputed territory" under "de facto Moroccan administration". ${ }^{133}$

Portugal declares in Front Polisario that Western Sahara is a "territory de facto administered by Morocco". ${ }^{134}$ The concept of "de facto administering power" does not exist in international law, ${ }^{135}$ and thus cannot be used as a legal basis for the conclusion of international agreements which, unlike the signature of contracts with private companies, is "an attribute of (...) sovereignty". ${ }^{136}$ Its adoption seems to have served the sole purpose of providing an appearance of legal capacity to Morocco to adopt international Treaties applicable to Western Sahara. ${ }^{137}$

The qualification of Western Sahara as a territory under de facto Moroccan administration opened the path to the argument that the Council has carte blanche to adopt agreements which are not to the detriment of the population of a disputed territory. ${ }^{138}$

The General Court concluded in Odigitria that the EU had to be recognized a wide discretion in the implementation of its external action in what regards disputed territories because:

"If (it) opposed the claims of the States concerning the zones over which they claim to have jurisdiction or opposed the exercise of that jurisdiction when a dispute exists, those non-member countries would very probably refuse to conclude (...) agreements with the (EU). Moreover, if the (EU) asked for zones to which other States lay claim to be excluded, that move would certainly be interpreted as interference by the Community in those disputes". 139

Odigitria concerned fisheries agreements concluded by the Union with Senegal and the Guinea-Bissau, which had not excluded from their territorial scope maritime zones which were subject to reciprocal claims by the two States. This case law is not applicable to Western Sahara where there is no territorial or boundary dispute which the EU should refrain from interfering in. ${ }^{140}$

\footnotetext{
${ }^{131} I d$., para. 2.

${ }^{132}$ Ministério dos Negócios Estrangeiros, “Observações da República Portuguesa no Processo No. C-266/17 Western Sahara Campaign”, July 27, 2016, paras. 19 and 23.

${ }^{133}$ Ministério dos Negócios Estrangeiros, "Articulado de Intervenção da República Portuguesa no Processo No. C-104/16 P Conselho/Frente Polisário”, May 23, 2016, paras. 8-9 and 15.

${ }^{134} I d$., para. 15.

${ }^{135}$ Eva Kassoti, “The EU and Western Sahara: An Assessment of Recent Developments”, 756-57.

${ }_{136}$ Advocate General Wathelet, Opinion delivered on January 10, 2018, Western Sahara Campaign, C-266/16, ECLI:EU:C:2018:1, para. 223 and 232, referring to the Permanent Court of International Justice case SS Wimbledon (United Kingdom and Others v. Germany), judgment of August 17, 1923 (PCIJ Series A, No. 1, 25).

${ }^{137}$ Eva Kassoti, “The EU and Western Sahara: An Assessment of Recent Developments”,755.

${ }^{138}$ Judgment of December 10, 2015, Front Polisario v Council, T-512/12, ECLI:EU:T:2015:953, paras. 216221 and 226. See also Ministério dos Negócios Estrangeiros, "Articulado de Intervenção da República Portuguesa no Processo No. C-104/16 P Conselho/Frente Polisário”, May 23, 2016, para. 21.

${ }^{139}$ Judgement of July 6, 1995, Odigitria v Council and Commission, T-572/93, ECLI:EU:T:1995:131, para. 38..

${ }_{140}$ Advocate General Wathelet, opinion of September 13, 2016, C-104/96, Council v Front Polisario, ECLI:EU:C:2016:677, para. 74
} 
Western Sahara is a non-self-governing territory within the meaning of Article 73 of the UN Charter. It has the exact same status as East Timor had in 1989 when Australia concluded an agreement with Indonesia that allowed both parties to share the hydrocarbon resources of the Timor Sea without establishing a definitive maritime border. ${ }^{141}$

East Timor was a former Portuguese colony that was invaded (1975) and annexed (1976) by Indonesia. ${ }^{142}$ Notwithstanding several UN Security Council and General Assembly resolutions which called for the withdrawal of Indonesian forces and proclaimed the Timorese people's right to self-determination, ${ }^{143}$ the occupation lasted until 1999. During this period, Australia moved away from its original condemnation of the invasion ${ }^{144}$ and, significantly for the case at hand, declared that the start of the negotiations for the conclusion of the Timor Gap Treaty. This signified a "de jure recognition by Australia of the Indonesian incorporation of East Timor". ${ }^{145}$

Portugal reacted by filling a claim against Australia in the International Court of Justice where it argued that, by entering into the Timor Gap Treaty, Australia "failed to observe (...) the obligation to respect the duties and powers of [Portugal as] the administering Power [of East Timor] (...) and (...) the right of the people of East Timor to self-determination and the related rights". ${ }^{146}$ Under international law, Portugal contended that, in spite of the Indonesian occupation, Australia could conclude an international treaty applicable to East Timor only with Portugal, given its status as administering power of that non-selfgoverning territory. ${ }^{147}$

The International Court of Justice refused to consider the merits of the claim, as this would require the determination of rights and obligations of a third state Indonesia - in the absence of the consent of that state to accept the jurisdiction of the tribunal. ${ }^{148}$ Nevertheless, the court did not miss the opportunity to declare that self-determination is an erga omnes right and an essential principle of contemporary international law. ${ }^{149}$ This decision bolstered the independence cause, which became a reality on 20 May 2002, following a referendum held on 30 August 1999, where 78.5\% of the Timorese people voted for independence from Indonesia.

\footnotetext{
${ }^{141}$ Treaty between Australia and the Republic of Indonesia on the Zone of Cooperation in an Area between the Indonesian Province of East Timor and Northern Australia, (December 11, 1989), [1991] A.T.S. 9 (entered into force February 9, 1991).

${ }^{142}$ International Court of Justice, East Timor (Portugal v. Australia), judgment, ICJ Reports 1995, 90, para. 13.

${ }^{143}$ V.g. General Assembly Resolution 3485 (XXX) (December 12, 1975); Security Council Resolution 384 (December 22, 1975); Security Council Resolution 389 (April 22, 1976); General Assembly Resolution 31/53 (December 1, 1976); General Assembly Resolution 32/34 (November 28, 1977); General Assembly Resolution 33/39 (December 13, 1978); General Assembly Resolution 34/40 (November 21, 1979); General Assembly Resolution 35/27 (November 11, 1980); General Assembly Resolution 36/50 (November 24, 1981); General Assembly Resolution 37/30 (November 23, 1982). ${ }^{144}$ Australia voted for General Assembly Resolution 3485 (XXX) (December 12, 1975), which called for the withdrawal of Indonesian forces. Regarding the recognition of East Timor as a part of Indonesia, see William T. Onorato and Mark J. Valencia, "The New Timor Gap Treaty: Legal and Political Implications", ICSID Review 59 (2000): 77 (stating that in 1985 Australia became the "only western country to formally recognize the Indonesian takeover of East Timor").

${ }^{145}$ International Court of Justice, East Timor (Portugal v. Australia), judgment, ICJ Reports 1995, 90, para. 17.

${ }^{146}$ Id., para. 1.

${ }^{147} I d$., para. 10.

${ }^{148} I d$., para. 26.

${ }^{149} I d$., para. 29.
} 
The decision of the Portuguese government to go to the The Hague court in the 90's was part of a strategy to raise awareness in the international community over the illegal invasion and annexation of East Timor by Indonesia. ${ }^{150}$

This behaviour marks a shocking contrast to the interventions before the Court of Justice in Front Polisario and Western Sahara Campaign, where the Portuguese government was at pains to neutralize the only court with jurisdiction to review the external action of the Union in order to ascertain whether that action contributed to "the strict observance (...) of international law (and the) respect for the principles of the UN Charter" [Article 3(5) TEU)]. Contrary to the Portuguese Government position in Western Sahara Campaign, far from being programmatic, Article 3(5) TEU, read together with the first subparagraph of Article 21(1) TEU, Article 21(2)(b) and (c) TEU, Article 23 TEU and Article 205 TFEU, require compliance with human rights and international law on the part "of all actions of the EU". ${ }^{151}$

The Portuguese Government adamantly refuses to admit to have taken a contradictory position on self-determination of occupied non-self-governed territories. The reply to the request for access to the statement for intervention lodged by the Parliamentary Group of Bloco de Esquerda ends with the remark that "by supporting the incompetence of the (Court of Justice of the EU), the Portuguese position (in Front Polisario) is coherent with the position embraced by Portugal (in the East Timor case before the International Court of Justice) whereas, contrary to the (International Court of Justice), the Court of Justice of the EU vocation is not to solve matters of international law". ${ }^{152}$ This is rather hypocritical as the Portuguese Government knows very well that the International Court of Justice does not have jurisdiction to rule on the validity of the EU/Morocco agreements: Morocco does not accept the jurisdiction of the International Court of Justice, while the EU is not a State and thus cannot be a party in cases in The Hague (Article 34 of the Statute of the International Court of Justice).

The Portuguese double standard did not go unnoticed to Advocate General Wathelet in Western Sabara Campaign, which commented that in light of the position taken in the East Timor case, it was "scarcely surprising that, in its written observations lodged in the present case, the Portuguese Government did not adopt a position on the validity of the contested measures", "(n)or did (...) answer the questions put to it by the Court, or participate in the hearing." 153

\section{Conclusions}

The written declaration of the sole abstaining member of the Portuguese Parliament on the solidarity vote on Western Sahara's self-determination is a perfect mirror of the Portuguese constraints on this question. ${ }^{154}$ Moral and legal imperatives

\footnotetext{
${ }^{150}$ Francisco Pereira Coutinho e Francisco Briosa e Gala, "David and Goliath Revisited”, 437.

151 Advocate General Wathelet, Opinion delivered on January 10, 2018, Western Sahara Campaign, C-266/16, ECLI:EU:C:2018:1, footnote 57, and Judgment of the Court of Justice of June 14, 2016, Parliament v Council, C-263/14, EU:C:2016:435, para. 47.

${ }^{152}$ Ministério dos Negócios Estrangeiros, "Resposta ao Requerimento No. 180/XIII/2 Ofício No. 4494, de 28 de julho de 2017”, para. 3, available at https:/ / www.parlamento.pt/ActividadeParlamentar/ Paginas/DetalhePerguntaRequerimento.aspx?BID=102435 (accessed on June 25, 2019).

${ }^{153}$ Advocate General Wathelet, Opinion delivered on January 10, 2018, Western Sahara Campaign, C-266/16, ECLI:EU:C:2018:1, footnote 191.

154 “Declaração de voto do Deputado do CDS-PP, João Rebelo, relativa ao voto No. 537/XIII (3. ${ }^{a}$ ),
} 
impel the pursuit of an idealistic diplomacy of unconditional support of the free exercise of the right to self-determination of the Sahrawi people. Political, strategic, economic, historical and cultural ties dictate a realpolitik aimed at fostering diplomatic relations with Morocco without shunning Algeria, another key stakeholder in the Maghreb region.

The plan to "having a cake and eating it too" diplomacy regarding Western Sahara is to follow an "impartial" 155 , "equidistant"156 and "balanced"157 position in the conflict - v. g. by abstaining in UN Assembly General resolutions sponsored by Algeria while encouraging the parties to strive for a political compromise. ${ }^{158}$

Such a strategy has obvious shortcomings which were exposed after the Court of Justice ceased in Front Polisario, the very convenient de facto application of the EU/ Morocco agreements in Western Sahara. The Portuguese Government followed the EU's path in picking Morocco's side in the conflict by lodging written interventions aimed at neutralizing the Court of Justice of the EU and by supporting Council decisions that expressly extend EU/Morocco agreements to Western Sahara in breach of EU and international law. These agreements will most likely end again in the Court of Justice of the EU where the Portuguese Government will have yet another chance to either stick to a realpolitik diplomacy, revert to an idealistic diplomacy following the Parliament's lead or play dead in the hope that no one notices it.

Diário da Assembleia da República, I Série, No. 84, May 12, 2018, 61.

${ }^{155}$ Ministério dos Negócios Estrangeiros, "Resposta ao requerimento No. 1290/X/2. a. Ofício No. 6827, de 30 de abril”, Diário da Assembleia da República, Série B, No. 51/X/2, Supl., July 31, 2007, 45; Ministério dos Negócios Estrangeiros, "Resposta ao requerimento No. 1325/X/2. Ofício No. 5417, de 2 de agosto", Diário da Assembleia da República, Série B, No. 51/X/2, Supl., August 6, 2007, 38; Ministério dos Negócios Estrangeiros, "Resposta ao requerimento No. 1799/X/2. Ofício No. 6448, de 14 de setembro de 2007", Diário da Assembleia da República, Série B, No. 5/X/3, Supl., September 9, 2007, 144 .

${ }^{156}$ Ministério dos Negócios Estrangeiros, "Resposta à pergunta No. 1176/XII/4. Ofício No. 3714, de 23 de junho de 2015", available at https://www.parlamento.pt/ActividadeParlamentar/Paginas/ DetalhePerguntaRequerimento.aspx?BID=86443 (accessed on June 25, 2019).

${ }^{157}$ Ibidem.

${ }^{158}$ Declaration of vote of the Representative of Portugal, General Assembly, Fourth Committee, $9^{\text {th }}$ Meeting, "Fourth Committee Approves Text on Western Sahara at Conclusion of Debate on Decolonization Issues", GA/SPD/348, October 13, 2006. 